\title{
Ivabradine in Postural Orthostatic Tachycardia Syndrome: A Review of the Literature
}

Faryal Tahir $^{1}$, Taha Bin Arif ${ }^{1}$, Zainab Majid ${ }^{1}$, Jawad Ahmed ${ }^{1}$, Muhammad Khalid ${ }^{2,} 3$

1. Internal Medicine, Dow University of Health Sciences, Karachi, PAK 2. Cardiology, Kansas City University of Medicine and Biosciences, Joplin, USA 3. Cardiology, Ascension Via Christi Hospital, Pittsburg, USA

Corresponding author: Jawad Ahmed, jawadahmedd13@gmail.com

\begin{abstract}
Postural orthostatic tachycardia syndrome (POTS) is an autonomic disorder characterized by symptoms such as palpitations, dyspnea, chest discomfort, and lightheadedness affecting various systems. The pathophysiology of POTS is not completely understood due to a variety of symptoms showing that the disease is multifactorial. There is no approved uniform management strategy for POTS and hence, no drug has been approved by the United States (US) Food and Drug Administration (FDA) for it. Ivabradine is an FDA-approved drug for stable symptomatic heart failure (HF) and patients with an ejection fraction (EF) of $\leqslant 35 \%$. Previous studies have depicted improvement in symptoms of POTS with the use of ivabradine. It is a selective inhibitor of funny sodium channels $\left(\mathrm{I}_{\mathrm{f}}\right)$ in the sinoatrial $(\mathrm{SA})$ node cells resulting in the prolongation of the slow diastolic depolarization (phase IV) and reduction in the heart rate (HR). Although beta-adrenoceptor blockers are commonly used to lower HR in patients with POTS, they are less ideal due to numerous adverse effects. This review aims to provide a comprehensive and up-to-date picture of all the studies and case reports that utilized ivabradine for the treatment of POTS along with a precise overview of epidemiology, pathophysiology, and types of POTS. To conclude, we recommend further research on the effectiveness of ivabradine in patients who experience symptoms of POTS. Other than stable chronic angina pectoris, its application in this setting has been proven to be effective and safe. Further evaluation by means of randomized control trials is required to encourage use of this HR-lowering agent in common disorders other than HF and stable angina, i.e. POTS.
\end{abstract}

Received 04/16/2020 Review began 04/20/2020 Review ended 04/20/2020 Published 04/28/2020

\section{() Copyright 2020} Tahir et al. This is an open access article distributed under the terms of the Creative Commons Attribution License CC-BY 4.0., which permits unrestricted use, distribution, and reproduction in any medium, provided the original author and source are credited.
Categories: Cardiology, Internal Medicine

Keywords: postural orthostatic tachycardia syndrome, postural tachycardia syndrome, pots, ivabradine, neuropathic pots, hyperadrenergic pots, hypovolemic pots, autoimmune pots, deconditioning pots, heart rate-lowering drug

\section{Introduction And Background}

The first informal mention of postural orthostatic tachycardia syndrome (POTS) was by Da Costa, in 1871, who referred to it as "soldier's heart" or "irritable heart" [1]. However, Schondorf and Low, in 1993, first described POTS in the adult population as an increase in the heart rate (HR) in a symptomatic patient by more than 30 beats per $\min (\mathrm{bpm})$ when the patient moves from supine to upright position [2]. In 2015, Heart Rhythm Society defined POTS on the basis of three points: (1) a clinical syndrome characterized by symptoms of lightheadedness, blurring of vision, palpitations, intolerance to exercise, and fatigue; (2) an increase of $\geqslant 30 \mathrm{bpm}$ ( $\geqslant 40 \mathrm{bpm}$ in those aged 12-19 years) in the HR when the person stands up from a recumbent position; and (3) absence of orthostatic hypotension [3]. Orthostatic hypotension is characterized by a more than $20 \mathrm{mmHg}$ drop in systolic blood pressure (BP) on standing [3]. The incidence of POTS varies globally from $0.2 \%$ to $1 \%$ in the developed countries with an increased prevalence among females, Caucasian race, and individuals from 13 to 50 years of age [4,5,6-8]. The affected individuals account for 3,000,000 cases alone in the United States of America (USA) [9]. A recent 2019 study has shown that the incidence of POTS has increased fourfold since 2000 [8].

POTS is an autonomic disorder characterized by symptoms such as palpitations, dyspnea, chest discomfort, lightheadedness, nausea, blurred vision, chronic fatigue, sleeping abnormalities, migraines, hypermobile joints, abdominal pain, irritable bowel, and bladder symptoms as well affecting various systems $[9,10]$. Only $30 \%$ of individuals have reported fainting along with the symptoms of POTS [9]. Usually, there is a two-year (median) delay in the diagnosis of disease from the onset of symptoms [7]. The pathophysiology of POTS is not completely understood due to a variety of symptoms showing that the disease is multifactorial $[4,9,10]$. Chronic fatigue syndrome, inappropriate sinus tachycardia, and vasovagal syncope are few conditions associated with POTS [4].

There is no approved uniform management strategy for POTS and hence, no drug has been approved by the US Food and Drug Administration (FDA) for it [4]. Non-pharmacological therapies include lifestyle modifications such as increased hydration and salt intake, and use of support stockings [11]. Pharmacological therapies include beta-blockers (first line), alpha-agonists (first or second line), mineralocorticoids (second line), selective serotonin reuptake inhibitors (SSRIs), and selective serotoninnorepinephrine reuptake inhibitors (SSNRIs), and rarely used drugs include pyridostigmine, desmopressin, 


\section{Cureus}

and erythropoietin $[4,11]$. However, there has been evidence of beneficial outcomes with the use of ivabradine in POTS patients, as seen in prospective and retrospective studies [12-16].

Ivabradine is an FDA-approved drug for stable symptomatic heart failure (HF) and patients with an ejection fraction (EF) of $\leqslant 35 \%[17,18]$. European Society of Cardiology recommends ivabradine as second-line therapy for patients whose angina has been poorly controlled by other medications, namely calcium-channel blockers (CCBs), beta-blockers, or nitrates (short-acting) [19].

Ivabradine increases the diastolic time and reduces the HR by inhibiting channels responsible for maintaining cardiac pacemaker current, $\mathrm{I}_{\mathrm{f}}$ (funny current). The selective blocking of these trans-membrane ion channels that conduct the inward depolarizing sodium $(\mathrm{Na})$ and potassium $(\mathrm{K})$ current slows down the HR without affecting systemic vascular resistance and cardiac inotropy [18,20,21]. Ivabradine has been associated with many severe side effects such as bradycardia, heart block, sinus arrest, QT prolongation, torsades de pointes, and fetal toxicity. Other less severe side effects include, but are not limited to, vertigo, diplopia, rash, and hypotension [17,18].

Ivabradine is not an FDA-approved drug for POTS but due to its ability to reduce HR, it has shown improvement in POTS patients in many studies [12-16]. This review aims to provide a comprehensive and up-to-date picture of all the studies and case reports that utilized ivabradine for the treatment of POTS along with a precise overview of epidemiology, pathophysiology, and types of POTS.

\section{Review}

POTS is a heterogeneous blood circulation disorder characterized by orthostatic hypotension and tachycardia with the HR increasing by at least $30 \mathrm{bpm}$ in adults or by $40 \mathrm{bpm}$ in adolescents during the first 10 minutes of standing from a recumbent position $[3,11]$. Patients with POTS often complain of postural tachycardia, headache, abdominal discomfort, dizziness, pre-syncope or syncope, nausea, tremors, anxiety, sleep disturbance, and chronic fatigue that significantly impair their quality of life [11]. The diagnostic criteria for POTS are illustrated in Figure 1.

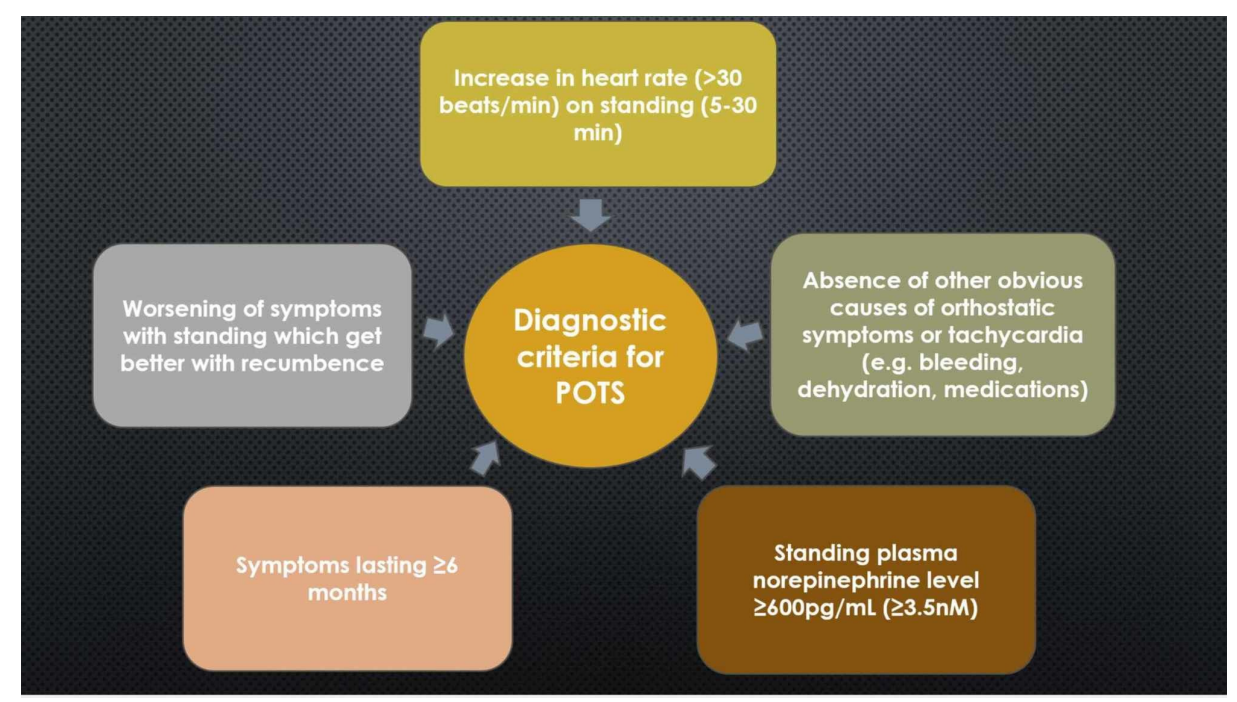

FIGURE 1: Diagnostic criteria for POTS

Adapted from [10].

POTS: postural orthostatic tachycardia syndrome

Previously, POTS was labeled as “soldier's heart” or “irritable heart” when it was first reported, in 1871, by Da Costa who described inappropriate tachycardia in civil war soldiers [1]. However, it has also been misdiagnosed as psychiatric illness such as depression and anxiety in recent times [10].

\section{Prevalence}

Being classified as the most common type of orthostatic intolerance (OI), POTS affects about $1 \%$ of the US population [2,9]. A majority of patients diagnosed with POTS fall in the 13- to 50-year age group [6]. Women are found to be more afflicted by POTS with a ratio of 4-5:1 [22]. A retrospective study conducted in the pediatric population of Philadelphia reported the demographics of POTS that showed a higher incidence among Caucasians (94.1\%) and females (77.5\%). Furthermore, it was noticed that the median age of onset of 
symptoms in patients under 18 years of age was 13.1 years with a median duration of 2 years before diagnosis [7].

\section{Etiology and types of POTS}

The etiology of POTS varies with its types, as described below in Table 1, resulting in tachycardia secondary to cardiovascular deconditioning.

\begin{tabular}{|c|c|}
\hline Type of РОTS & Description \\
\hline $\begin{array}{l}\text { Neuropathic } \\
\text { POTS }\end{array}$ & $\begin{array}{l}\text { Neuropathic POTS is an autonomic neuropathy characterized predominantly by lower limb sympathetic } \\
\text { denervation leading to reduced venoconstriction and venous pooling [23]. One study highlighted that despite } \\
\text { normal NE spillover, POTS patients exhibited decreased NE release in the lower extremities demonstrating } \\
\text { dysfunctional NE reuptake secondary to injured peripheral nerves [24]. }\end{array}$ \\
\hline $\begin{array}{l}\text { Hyperadrenergic } \\
\text { РОTS }\end{array}$ & $\begin{array}{l}\text { Approximately } 30 \%-60 \% \text { of POTS patients fall under the category of hyperadrenergic type. An elevated standing } \\
\text { plasma NE level of } \geq 600 \mathrm{pg} / \mathrm{mL} \text { with an increased sympathetic tone manifesting as palpitations, tremors, } \\
\text { hypertension, tachycardia, and anxiety is characteristic [23]. One case depicted the loss-of-function mutation of } \\
\text { the SLC6A2 gene resulting in deficient NET and elevated mean supine HR [25]. Medications like TCAs, } \\
\text { sympathomimetics (e.g., methylphenidate), and NE reuptake inhibitors (e.g., bupropion) are more frequently seen } \\
\text { to cause NET block [23]. }\end{array}$ \\
\hline $\begin{array}{l}\text { Hypovolemic } \\
\text { РОTS }\end{array}$ & $\begin{array}{l}\text { Although the severity of hypovolemia varies between studies, about } 70 \% \text { of patients with POTS show decreased } \\
\text { plasma, RBCs, and total blood volumes }[3,23,26] \text {. An impairment in the RAAS associated with a lower level of } \\
\text { renin and aldosterone can lead to low volume state in POTS patients [27]. }\end{array}$ \\
\hline $\begin{array}{l}\text { Autoimmune } \\
\text { РОTS }\end{array}$ & $\begin{array}{l}\text { Considering the similarities (female predominance, post-viral onset, elevated autoimmune markers) with other } \\
\text { autoimmune disorders like RA, SLE, and sjogren syndrome, an autoimmune hypothesis has been proposed for } \\
\text { POTS [28]. POTS patients have been observed to produce increased autoantibodies. A study found that } 25 \% \text { of } \\
\text { patients had positive ANAs with Hashimoto's thyroiditis as the most prevalent disorder in these individuals [29]. }\end{array}$ \\
\hline $\begin{array}{l}\text { Deconditioning } \\
\text { РОTS }\end{array}$ & $\begin{array}{l}\text { POTS patients often have physical and cardiovascular deconditioning, but its presence as either cause or effect is } \\
\text { unidentified. Furthermore, the degree of deconditioning does not inevitably correspond to objective laboratory } \\
\text { and autonomic findings [3]. }\end{array}$ \\
\hline
\end{tabular}

\section{TABLE 1: Types of POTS with description}

POTS: postural orthostatic tachycardia syndrome, NE: norepinephrine, NET: norepinephrine transport, HR: heart rate, TCAs: tricyclic antidepressants, RBCs: red blood cells, RAAS: renin-angiotensin-aldosterone system, RA: rheumatoid arthritis, SLE: systemic lupus erythromatosus, ANAs: antinuclear antibodies

\section{Pathophysiology of POTS}

POTS has heterogeneous pathophysiology, including excessive sympathetic stimulation, defective peripheral autonomic function, hypovolemia, or autoimmune dysfunction $[4,23,28]$. Orthostatic pathologies reflect gravity-dependent physiology as the total effective circulatory volume reduces due to the shift of intravascular volume to interstitial space. As a consequence, an increase in the sympathetic stimulation manifested as increased cardiac contractility, HR, and peripheral vascular resistance (PVR) occurs secondary to a subsequent reduction in stroke volume. Despite an extravagant sympathetic response to postural changes such as standing, POTS patients present with persistent decreased volume, consummating into a common terminal pathway of tachycardia in the presence of OI on standing [28]. However, the mechanism behind the pathophysiology of POTS is not completely understood due to the complex overlap of cardiovascular, neuropathic, renal, immune, and hematologic systems [5].

\section{Management of POTS}

POTS is treated by both pharmacological and non-pharmacological approaches that solely depend on the definitive diagnosis, patient education, and compliance with the therapy.

Due to its non-specific and chronic debilitating nature, the management of POTS relies on the patient's knowledge and management of expectations. The need for a multi-faceted therapeutic approach through the assessment of patient's understanding and follow-ups on questions and concerns cannot be overemphasized [5]. Regardless, each approach should be customized according to the predominant subtype (e.g., hypovolemic, hyperadrenergic). 
gradual physical exercise regimen [5]. Considering that the symptoms may exacerbate with increased activity, the patient can begin with low-intensity exercise programs concentrated on avoiding upright posturing (e.g., swimming) with incremental progression over three months [4,28]. A study found that 10 out of 19 (53\%) patients no longer met POTS criteria following a three-month exercise regimen. Furthermore, an $11 \%$ increase in maximal oxygen intake, $12 \%$ increase in left ventricular mass, and $8 \%$ rise in end-diastolic volume were noticed in these patients [30]. Other non-pharmacologic interventions include increased fluid and salt intake, compression garments, and physical counter-maneuvers like leg crossing, muscle contraction, and forward bending $[23,31]$.

Pharmacologic therapy is not considered a first-line intervention for POTS and is usually administered in severe or refractory cases [4]. There is no proven clinical effectiveness of pharmacologic therapies over conservative non-pharmacologic interventions, although the patient should be monitored for potential adverse effects (AEs) and drug interactions. There is no approved medication for the treatment of POTS by the US FDA $[4,28]$. Some common pharmacologic agents that are used off-label for the treatment of POTS are summarized below in Table 2.

\begin{tabular}{|c|c|}
\hline Drug & Features \\
\hline Fludrocortisone & $\begin{array}{l}\text { It is a synthetic mineralocorticoid that promotes renal Na reabsorption and loss of } \mathrm{K} \text {. Adverse effects include } \\
\text { hypertension, hypokalemia, headache, edema, and HF [28]. }\end{array}$ \\
\hline Midodrine & $\begin{array}{l}\text { It is an alpha-1 adrenergic agonist that increases arteriolar and venous tone resulting in an increased venous return } \\
\text { that can be beneficial for hypovolemic phenotypes. Supine hypertension, paresthesias, urinary retention, and } \\
\text { urgency are some of the limitations [3]. }\end{array}$ \\
\hline $\begin{array}{l}\text { Clonidine and } \\
\text { alpha- } \\
\text { methyldopa }\end{array}$ & $\begin{array}{l}\text { Hyperadrenergic POTS patients with hypertension can benefit from these centrally acting alpha-2 agonists. They } \\
\text { reduce sympathetic tone and decrease PVR, BP, and HR. However, the patient should be monitored for cognitive } \\
\text { clouding, headache, skin rash, fatigue, and sedation [28]. }\end{array}$ \\
\hline $\begin{array}{l}\text { Propranolol, } \\
\text { metoprolol }\end{array}$ & $\begin{array}{l}\text { Beta-adrenergic blockers decrease HR and cardiac contractility by blocking beta-adrenergic receptor activation. } \\
\text { Non-selective beta-blockers (propranolol) can also reduce splenic vasoconstriction via beta-2 inhibition. } \\
\text { Bradycardia, hypotension, fatigue, and syncope are common adverse effects [28]. }\end{array}$ \\
\hline Pyridostigmine & $\begin{array}{l}\text { It is an acetylcholinesterase inhibitor that increases acetylcholine levels in autonomic ganglia and peripheral } \\
\text { muscarinic receptors. its continual use is limited by abdominal pain, diarrhea, vomiting, and dysmenorrhea [4]. }\end{array}$ \\
\hline
\end{tabular}

\section{TABLE 2: Pharmacologic agents for the treatment of POTS}

HF: heart failure, POTS: postural orthostatic tachycardia syndrome, PVR: peripheral vascular resistance, BP: blood pressure, HR: heart rate

Medications that aggravate specific symptoms like tachycardia (e.g., sympathomimetics including amphetamines, SSRIs, and SSNRIs) or deteriorate OI (e.g., CCBs, diuretics, opiates, nitrates, and tricyclic antidepressants) should be avoided [28].

\section{Ivabradine for the treatment of POTS}

Ivabradine is a selective inhibitor of funny sodium channels $\left(\mathrm{I}_{\mathrm{f}}\right)$ in the sinoatrial $(\mathrm{SA})$ node cells resulting into the prolongation of the slow diastolic depolarization (phase IV) and eventually, reduction in HR [32]. In 2015, FDA approved ivabradine for reducing the risk of hospitalization for worsening HF in adults with stable, symptomatic chronic HF with reduced EF and for the treatment of stable, symptomatic HF due to dilated cardiomyopathy in pediatric patients (aged 6 months or older) [20]. Ivabradine can also be used for patients with chronic stable angina who cannot take beta-blockers. It reduces HR by decreasing myocardial oxygen demand and maintaining the viability of myocardial cells. In addition, it prolongs diastolic perfusion time and improves coronary flow velocity reserves. These physiological changes result into an increased ischemic threshold and an improvement in angina [33]. Ivabradine reduces HR almost linearly with an oral dose ranging from 0.5 to $24 \mathrm{mg}$. However, HR is reduced nonlinearly reaching a plateau at higher doses [34]. Ivabradine has no significant effect on BP as it does not affect myocardial contractility [35]. It has minimal AEs and a relatively better tolerance according to previous clinical trials. Some common AEs include bradycardia, hypertension, atrial fibrillation (AF), luminous phenomena, or visual brightness [20].The molecular structure of ivabradine is shown in Figure 2 [20]. 


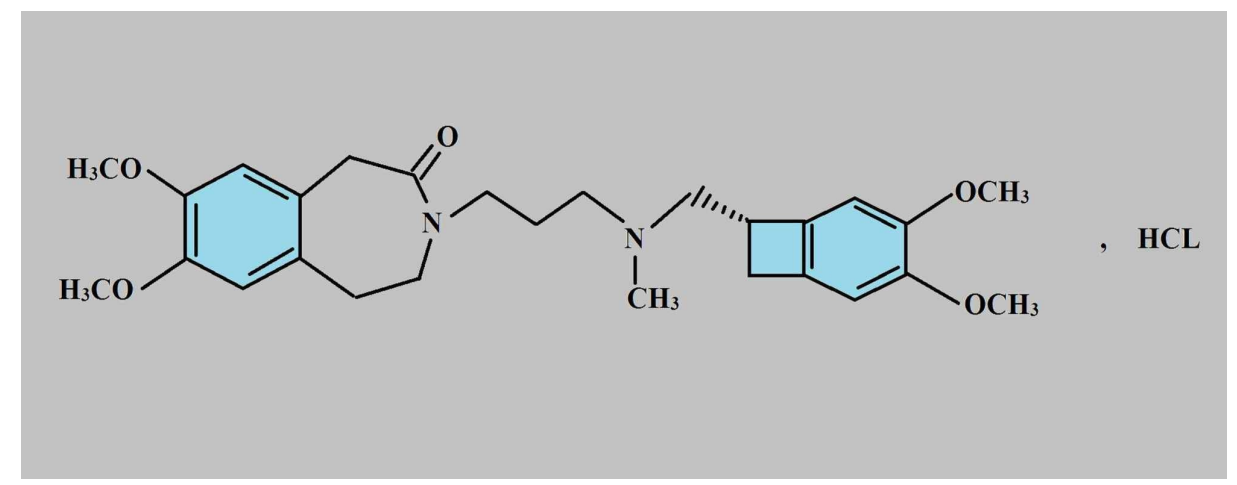

FIGURE 2: Structure of ivabradine

Adapted from [20].

Beta-adrenoceptor blockers are commonly used to lower HR in patients with POTS; however, they are less ideal due to numerous AEs. Although not FDA approved, previous studies have depicted improvement in symptoms of POTS with the use of ivabradine. According to a study by Ruzieh et al., the best response rate (88.4\%) was shown for palpitations, a considerably troubling and the most prevalent symptom among these patients [16]. The improvement is highly linked to the nature of ivabradine as a selective SA node blocker that decreases HR without affecting cardiovascular physiology. The response to ivabradine was higher in their cohort as compared to previous studies with a significant improvement in other symptoms, such as lightheadedness (76.1\%), syncope (60.7\%), fatigue (57.5\%), trouble concentrating (55.2\%), and dyspnea (42.9\%) [16]. Similarly, studies by Sutton et al. and McDonald et al. demonstrated that ivabradine may be beneficial in conditions where sinus tachycardia is the main feature [12,14]. Ivabradine showed improvement in 18 out of 25 patients with vasovagal syncope and tachycardia on the tilt table test with no major AEs [12].

\section{POTS and ivabradine: what do studies say?}

A total of five researches were identified that studied the use of ivabradine in POTS patients either prospectively or retrospectively.

Sutton et al. published a pilot study, in the year 2014, in which the effect of ivabradine was assessed in patients with vasovagal shock who manifested with sinus tachycardia on the head tilt, meeting the HR criteria for POTS [12]. The study population was 25 patients, with a mean age of 33 years, who presented with syncope, $92 \%$ of whom also experienced palpitations, during the period of 2008 to 2011. Ivabradine with a standard dose of $5 \mathrm{mg} /$ day was initiated, with a maximum dose of $20 \mathrm{mg} /$ day. The resting HR was charted that showed no signs of symptomatic bradycardia; however, repeat tilt testing was not performed. The drug was continued by all patients for a duration of 2-40 months with a mean dosage of $10.7 \mathrm{mg} / \mathrm{day}$ as once or twice daily medication. The results showed a complete resolution of symptoms in $32 \%$ of the patients, whereas $40 \%$ experienced great improvement in syncope. Remaining $28 \%$ of the patients discontinued the drug due to no improvement of symptoms, pregnancy, or side effects, the latter been reported as either non-specific or related to the retina [12].

In 2015, Barzilai and Jacob studied the effects of ivabradine on HR and BP in eight patients suffering from POTS for the past two years [13]. Following a series of the experimental protocol, the patients initially had their BP, HR, and RR measured and were laid supine on a tilt table for 30 minutes. This was followed by a sampling of the previously mentioned parameters and evaluation of the sympathetic and parasympathetic systems. The patients were then head uptilted at $70^{\circ}$ for 20 minutes and finally rested in the supine position. Ivabradine was administered at a single dose of $7.5 \mathrm{mg}$, along with the repetition of the protocol after 60-80 minutes. The drug was found effective in reducing the resting HR by $4 \pm 1 \mathrm{bpm}$ with a notable decrement from $118 \pm 4 \mathrm{bpm}$ to $101 \pm 5 \mathrm{bpm}$ after five minutes of head tilt. Moreover, the drug did not alter the BP and cardiovascular vagal and sympathetic tone and showed no significant side effects [13].

Another research was carried out, in the UK, by McDonald et al. analyzing similar effects of the drug on patients with POTS [14]. This retrospective case study was carried out on 20 patients from a tertiary cardiovascular ward who participated by filling a self-assessment tool, discussing their perception of drug effectiveness, changes in symptoms, and side effects. Nearly half (55\%) of the patients continued the use of ivabradine at the time of analysis with a mean duration of 25 weeks and mean drug dosage of $5 \mathrm{mg}$ in a single dose or two doses, and reported decreased episodes of palpitations and tachycardia. Improvement in fatigue was reported by $44 \%$ of the participants. Side effects were experienced by five patients, two of whom complained of visual disturbances and increased fatigue, the patient with the latter terminating his treatment [14]. 
Through the period of February 2008 to June 2014, Donne et al. retrospectively evaluated the pediatric population, less than 18 years of age, with POTS for the effects of ivabradine [15]. Using the pharmacy database, 22 patients were prescribed an initial dose of $5 \mathrm{mg}$ /day in two divided doses, and in $50 \%$ of the patients, the dose was adjusted with the mean value being $9.5 \mathrm{mg}$. During the median follow-up of 4.6 months, the majority (68\%) of the participants reported improved symptoms and decreased episodes of syncope. However, in six patients, the follow-up was of less than three months; ivabradine was terminated in four of them accounting for resolution of symptoms $(n=2)$, no improvement $(n=1)$, or worsening of syncope and palpitation $(\mathrm{n}=1)$. Side effect of mild phosphine was observed in only one patient. Decrement in the HR on resting electrocardiogram (EKG) analysis was observed from a mean of 82.5 to 71 , performed in $86 \%$ of the patients. Overall, the drug was considered safe for use in children less than 18 years of age [15].

A recent study carried out, in 2017, by Ruzieh et al. determined the efficacy of ivabradine in a comparatively larger sample size of 49 patients, the majority being females [16]. Based on the more substantial part of the cohort (78\%) reporting a noteworthy improvement, this study, like the others before, also concluded on the drug being productive for the treatment of POTS, given further placebo-controlled trials should be carried out. The initial dose of ivabradine in this study was $2.5 \mathrm{mg}$ in two doses and was tittered according to each patient. Side effects observed were related to visual brightness in nine and nausea in four patients. In follow-up values of vitals, no change in BP was recorded, whereas HR in sitting and standing positions was found to be lowered [16].

Table 3 summarizes all the above-mentioned studies evaluating outcomes of ivabradine therapy among POTS patients.

\begin{tabular}{|c|c|c|c|c|c|c|c|c|}
\hline $\begin{array}{l}\text { Author } \\
\text { (year) }\end{array}$ & Study type & $\begin{array}{l}\text { Study } \\
\text { duration }\end{array}$ & Objective & $\begin{array}{l}\text { No. of } \\
\text { patients } \\
\text { (mean } \\
\text { age) }\end{array}$ & $\begin{array}{l}\text { Drug } \\
\text { (dosage) }\end{array}$ & $\begin{array}{l}\text { Mean } \\
\text { duration } \\
\text { of } \\
\text { treatment }\end{array}$ & Results & $\begin{array}{l}\text { Adverse } \\
\text { reactions }\end{array}$ \\
\hline $\begin{array}{l}\text { Sutton et } \\
\text { al. (2014) } \\
\text { [12] }\end{array}$ & $\begin{array}{l}\text { Prospective } \\
\text { open-label } \\
\text { trial }\end{array}$ & $\begin{array}{l}\text { October } \\
\text { 2008- } \\
\text { December } \\
2011\end{array}$ & $\begin{array}{l}\text { To evaluate the response of a } \\
\text { subgroup of VVS patients to } \\
\text { ivabradine. }\end{array}$ & $\begin{array}{l}25(33 \\
\text { years })\end{array}$ & $\begin{array}{l}\text { Ivabradine } \\
(10.7 \\
\mathrm{mg} / \text { day })\end{array}$ & $\begin{array}{l}15 \\
\text { months }\end{array}$ & $\begin{array}{l}72 \% \text { of the patients gained benefit } \\
\text { from ivabradine with } 32 \% \text { becoming } \\
\text { completely asymptomatic. }\end{array}$ & $\begin{array}{l}\text { Visual side } \\
\text { effects }(9 \%) \text {, } \\
\text { unspecified side } \\
\text { effect }(4 \%)\end{array}$ \\
\hline $\begin{array}{l}\text { Barzilai et } \\
\text { al. (2015) } \\
\text { [13] }\end{array}$ & $\begin{array}{l}\text { Prospective } \\
\text { open-label } \\
\text { trial }\end{array}$ & - & $\begin{array}{l}\text { To study the effect of Ivabradine } \\
\text { on the hemodynamics and } \\
\text { sympathovagal balance in POTS } \\
\text { patients. }\end{array}$ & $\begin{array}{l}8(31 \pm \\
3 \text { years) }\end{array}$ & $\begin{array}{l}\text { Ivabradine } \\
\text { (7.5 mg) }\end{array}$ & $\begin{array}{l}\text { Single } \\
\text { dose }\end{array}$ & $\begin{array}{l}\text { Ivabradine decreased resting HR by } 4 \\
\pm 1 \text { bpm and from } 118 \pm 4 \text { to } 101 \pm 5 \\
\text { bpm after tilting for five minutes. }\end{array}$ & - \\
\hline $\begin{array}{l}\text { McDonald } \\
\text { et al. } \\
\text { (2011) [14] }\end{array}$ & $\begin{array}{l}\text { Retrospective } \\
\text { case-series }\end{array}$ & $\begin{array}{l}\text { January } \\
\text { 2008-July } \\
2010\end{array}$ & $\begin{array}{l}\text { To evaluate POTS patients treated } \\
\text { with ivabradine. }\end{array}$ & $\begin{array}{l}20(35 \pm \\
9.9 \\
\text { years })\end{array}$ & $\begin{array}{l}\text { Ivabradine } \\
\text { (5 mg/day) }\end{array}$ & 25 weeks & $\begin{array}{l}\text { Among patients treated with } \\
\text { ivabradine, } 60 \% \text { report a symptomatic } \\
\text { improvement. }\end{array}$ & $\begin{array}{l}\text { Visual } \\
\text { abnormalities } \\
(10 \%) \text {, dizziness } \\
(5 \%) \text {, fatigue } \\
(5 \%)\end{array}$ \\
\hline $\begin{array}{l}\text { Delle } \\
\text { Donne et } \\
\text { al. (2017) } \\
\text { [15] }\end{array}$ & $\begin{array}{l}\text { Retrospective } \\
\text { cohort study }\end{array}$ & $\begin{array}{l}\text { February } \\
\text { 2008- } \\
\text { June } 2014\end{array}$ & $\begin{array}{l}\text { To review the experience of } \\
\text { ivabradine evaluation among } \\
\text { pediatric patients with POTS. }\end{array}$ & $\begin{array}{l}22(14.5 \\
\text { years })\end{array}$ & $\begin{array}{l}\text { Ivabradine } \\
(9.5 \\
\mathrm{mg} / \text { day })\end{array}$ & $\begin{array}{l}3.7 \\
\text { months }\end{array}$ & $\begin{array}{l}\text { Among POTS patients younger than } 18 \\
\text { years of age, ivabradine produced } \\
\text { improvement of symptoms in } 68 \% \text {. }\end{array}$ & $\begin{array}{l}\text { Mild } \\
\text { phosphenes } \\
(4.5 \%)\end{array}$ \\
\hline $\begin{array}{l}\text { Ruzieh et } \\
\text { al. (2017) } \\
{[16]}\end{array}$ & $\begin{array}{l}\text { Retrospective } \\
\text { cohort study }\end{array}$ & $\begin{array}{l}\text { January } \\
2010- \\
\text { October } \\
2016\end{array}$ & $\begin{array}{l}\text { To examine the effects ivabradine } \\
\text { among POTS patients. }\end{array}$ & $\begin{array}{l}49(35.1 \\
\pm 10.35 \\
\text { years })\end{array}$ & $\begin{array}{l}\text { Ivabradine } \\
(10.9 \\
\mathrm{mg} / \text { day })\end{array}$ & $\begin{array}{l}\text { 3-12 } \\
\text { months }\end{array}$ & $\begin{array}{l}\text { Showing the efficacy of ivabradine in } \\
\text { POTS patients, nearly } 78 \% \text { of the } \\
\text { cohort reported a significant } \\
\text { improvement in symptoms. }\end{array}$ & $\begin{array}{l}\text { Visual } \\
\text { brightness } \\
(18 \%), \text { nausea } \\
(8.2 \%)\end{array}$ \\
\hline
\end{tabular}

\section{TABLE 3: Summary of studies evaluating outcomes of ivabradine in POTS}

VVS: vasovagal syncope, POTS: postural orthostatic tachycardia syndrome, HR: heart rate, bpm: beats per minute

\section{POTS and ivabradine: a review of case reports}

To further expand our knowledge regarding the practical implementations of ivabradine, we have taken the support of previously published case reports and analyzed the outcomes in terms of its effectiveness and side effects along with treatment duration (Table 4). All case reports published till date that discussed the outcome of ivabradine in POTS patients of every age and race were taken for the evaluation. An evaluation of these case reports shows $88 \%$ (eight out of nine) cases with female patients, and this high female-to-male 


\section{Cureus}

ratio is consistent with the previously published literature (Table 4) $[12-14,16]$. The mean age of the patients with symptoms of POTS and sympathetic dysfunction has been found to be 26.8 years, ranging from 17 to 42 years [36-44]. This figure is also coherent with the past studies of ivabradine assessment, in which the affected individuals were young and middle-aged adults. The patients with POTS usually experience symptoms of fluctuating HR and BP, lightheadedness on standing, extreme fatigue, nausea, and anxiety among other orthostatic symptoms. Patients among reported cases mostly experienced fatigue and palpitations, syncope, and lightheadedness on standing. Veins in the lower legs may particularly be affected by the sympathetic denervation, causing them to become atonic and giving rise to subsequent pooling of blood, and hence, the bluish discoloration of limbs experienced by some individuals [13]. Oztunc et al. described the symptoms of bruising, redness, and swelling of the hands and feet along with dizziness and tachycardia, the former probably accounting for the coexistence of Raynaud's phenomenon [36].

\begin{tabular}{|c|c|c|c|c|c|c|c|}
\hline $\begin{array}{l}\text { Author } \\
\text { (year) }\end{array}$ & $\begin{array}{l}\text { Patient } \\
\text { age (in } \\
\text { years), } \\
\text { sex }\end{array}$ & Presenting symptom & $\begin{array}{l}\text { lvabradine } \\
\text { dose }\end{array}$ & $\begin{array}{l}\text { Treatment } \\
\text { period }\end{array}$ & $\begin{array}{l}\text { Outcome of } \\
\text { treatment }\end{array}$ & $\begin{array}{l}\text { Adverse } \\
\text { effects }\end{array}$ & Other information \\
\hline $\begin{array}{l}\text { Oztunc } \\
\text { et al. } \\
\text { (2016) } \\
{[36]}\end{array}$ & $\begin{array}{l}17, \\
\text { female }\end{array}$ & $\begin{array}{l}\text { Bruising, redness, and } \\
\text { swelling on the hands } \\
\text { and feet after moving } \\
\text { from supine to upright } \\
\text { position }\end{array}$ & - & 6 months & $\begin{array}{l}\text { No complaint of } \\
\text { dizziness, bruising, or } \\
\text { palpitations during } \\
\text { follow-up }\end{array}$ & - & $\begin{array}{l}\text { Tilt table test increased HR (from } 80 \text { to } \\
128 \mathrm{bpm} \text { ) and BP (from 100/60 to 130/90 } \\
\mathrm{mmHg} \text { ); metoprolol } 1 \mathrm{mg} / \mathrm{kg} / \text { day ( } 2 \\
\text { months) and midodrine } 10 \mathrm{mg} \text { TD ( } 45 \\
\text { days) were given that showed no } \\
\text { beneficial effect }\end{array}$ \\
\hline $\begin{array}{l}\text { Ewan et } \\
\text { al. (2007) } \\
{[37]}\end{array}$ & $\begin{array}{l}21, \\
\text { female }\end{array}$ & $\begin{array}{l}\text { Fatigue }(\mathrm{FIS}=102) \text {, } \\
\text { orthostatic intolerance } \\
\text { (OGS=19), palpitations } \\
(\mathrm{HR}=120-160)\end{array}$ & $\begin{array}{l}2.5 \mathrm{mg} 12- \\
\text { hourly, } \\
\text { then } 5 \mathrm{mg} \\
\text { 12-hourly }\end{array}$ & - & $\begin{array}{l}\text { Improvement in } \\
\text { fatigue ( } F I S=52) \text {, } \\
\text { orthostatic } \\
\text { intolerance (OGS=9), } \\
\text { palpitations (HR=90- } \\
95)\end{array}$ & - & $\begin{array}{l}\text { Patient was unable to tolerate beta- } \\
\text { blockers and verapamil due to asthma } \\
\text { and nausea, respectively. }\end{array}$ \\
\hline $\begin{array}{l}\text { Khan et } \\
\text { al. (2009) } \\
\text { [38] }\end{array}$ & $\begin{array}{l}44, \\
\text { female }\end{array}$ & $\begin{array}{l}\text { Palpitations on standing } \\
\text { (107-140 bpm) }\end{array}$ & $\begin{array}{l}5 \text { mg 12- } \\
\text { hourly }\end{array}$ & 6 weeks & $\begin{array}{l}\text { Reduction of supine } \\
\text { and erect } \mathrm{HR} \text { to } 80 \\
\text { and } 90 \mathrm{bpm} \text {, } \\
\text { respectively, HR= } \\
<120 \text { bpm at } 6 \text {-week } \\
\text { checkup }\end{array}$ & $\begin{array}{l}\text { Mild } \\
\text { transient } \\
\text { visual } \\
\text { disturbances } \\
\text { (treatment } \\
\text { continued } \\
\text { despite } \\
\text { adverse } \\
\text { effect) }\end{array}$ & $\begin{array}{l}\text { Dual-chamber pacemaker implanted for } \\
\text { intermittent CHB, history of PAF, beta- } \\
\text { blockers poorly tolerated (Raynaud's } \\
\text { syndrome) }\end{array}$ \\
\hline $\begin{array}{l}\text { Jamil- } \\
\text { Copley } \\
\text { et al. } \\
\text { (2010) } \\
{[39]}\end{array}$ & $\begin{array}{l}25, \\
\text { female }\end{array}$ & $\begin{array}{l}\text { Recurrent pre-syncopal } \\
\text { and syncopal episodes } \\
(\mathrm{HR}=100 \mathrm{bpm} \text { and } \\
\mathrm{BP}=140 / 80 \mathrm{mmHg} \text { while } \\
\text { seated and } \mathrm{BP}=160 / 90 \\
\text { mmHg on standing) }\end{array}$ & $\begin{array}{l}5 \text { mg 12- } \\
\text { hourly }\end{array}$ & 3 weeks & $\begin{array}{l}\text { Dissolution of } \\
\text { palpitations (HR=90 } \\
\text { bpm) and syncopal } \\
\text { episodes }\end{array}$ & - & $\begin{array}{l}\text { Patient was a known case of essential } \\
\text { hypertension (took ramipril and } \\
\text { bisoprolol); tilt table test produced sinus } \\
\text { tachycardia (HR=146 bpm) }\end{array}$ \\
\hline $\begin{array}{l}\text { Nakatani } \\
\text { et al. } \\
\text { (2011) } \\
{[40]}\end{array}$ & $\begin{array}{l}42, \\
\text { female }\end{array}$ & $\begin{array}{l}\text { Postural palpitations } \\
\text { and syncope }\end{array}$ & $\begin{array}{l}2.5 \\
\mathrm{mg} / \text { day }\end{array}$ & $\begin{array}{l}\text { Ivabradine } \\
\text { was } \\
\text { discontinued } \\
\text { after adverse } \\
\text { reaction }\end{array}$ & $\begin{array}{l}\text { Ivabradine effectively } \\
\text { reduced resting and } \\
\text { standing HR, } \\
\text { improved orthostatic } \\
\text { symptoms with no } \\
\text { recurrence of } \\
\text { syncope }\end{array}$ & $\begin{array}{l}\text { Allergic } \\
\text { reaction }\end{array}$ & $\begin{array}{l}\text { Head-up tilt test increased HR to } 120 \\
\text { bpm without hypotension; alpha- } \\
\text { agonists, beta-blockers, } \mathrm{Ca}^{2+} \text {-channel } \\
\text { blockers, and digitalis were not tolerated; } \\
\text { sinus and } \mathrm{AV} \text { node ablation with } \\
\text { pacemaker implantation was performed } \\
\text { after terminating ivabradine }\end{array}$ \\
\hline $\begin{array}{l}\text { Aliyev et } \\
\text { al. (2010) } \\
{[41]}\end{array}$ & $\begin{array}{l}30, \\
\text { male }\end{array}$ & $\begin{array}{l}\text { Frequent syncopal } \\
\text { attacks precipitated } \\
\text { during upright position } \\
\text { and CSM, PAF }\end{array}$ & $\begin{array}{l}5 \mathrm{mg} 12- \\
\text { hourly }\end{array}$ & $\begin{array}{l}5 \text { days } \\
\text { (short-term } \\
\text { therapy) and } \\
6 \text { months } \\
\text { (follow-up) }\end{array}$ & $\begin{array}{l}\text { Short-term therapy } \\
\text { resulted in } \\
\text { disappearance of } \\
\text { syncopal episodes } \\
\text { during upright } \\
\text { position and CSM; no } \\
\text { syncope or AF on } \\
\text { follow-up }\end{array}$ & - & $\begin{array}{l}\text { Syncopal attacks associated with } \\
\text { HR= } 140 \mathrm{bpm} \text { plus sudden drop in BP }\end{array}$ \\
\hline $\begin{array}{l}\text { Cheema } \\
\text { et al. }\end{array}$ & 19, & stural syncopal & 2.5 mg 12- & & $\begin{array}{l}\text { Ivabradine resulted in } \\
\text { improvement of }\end{array}$ & & $\begin{array}{l}\text { The patient took excessive hydration, } \\
\text { salt, and fludrocortisone with no relief; }\end{array}$ \\
\hline
\end{tabular}




\section{Cureus}

\begin{tabular}{|c|c|c|c|c|c|c|c|}
\hline $\begin{array}{l}(2019) \\
{[42]}\end{array}$ & female & $\begin{array}{l}\text { episodes preceded by } \\
\text { palpitations }\end{array}$ & hourly & 6 months & $\begin{array}{l}\text { symptoms and } \\
\text { negative repeat tilt } \\
\text { tests }\end{array}$ & - & $\begin{array}{l}\text { patient had a history of head concussion } \\
3 \text { years ago; tilt table test increased the } \\
\text { HR up to } 148 \mathrm{bpm} \text { followed by LOC }\end{array}$ \\
\hline $\begin{array}{l}\text { Hersi } \\
(2010) \\
{[43]}\end{array}$ & $\begin{array}{l}25, \\
\text { female }\end{array}$ & $\begin{array}{l}\text { Fatigue, severe } \\
\text { weakness and } \\
\text { palpitations on standing } \\
(\mathrm{HR}=139 \mathrm{bpm}, \\
\mathrm{BP}=125 / 70 \mathrm{mmHg}) \text {, } \\
\text { tingling and coldness in } \\
\text { feet }\end{array}$ & $\begin{array}{l}5 \mathrm{mg} \mathrm{12-} \\
\text { hourly }\end{array}$ & $\begin{array}{l}2 \text { days } \\
\text { (short-term } \\
\text { therapy) and } \\
4 \text { months }\end{array}$ & $\begin{array}{l}\text { Short-term therapy } \\
\text { made her able to } \\
\text { stand without } \\
\text { weakness or } \\
\text { tachycardia (HR=80 } \\
\text { bpm) }\end{array}$ & - & $\begin{array}{l}\text { Patient ran out of Ivabradine after } 4 \\
\text { months, symptoms recurred, then } \\
\text { resolved again upon reinstituting the drug }\end{array}$ \\
\hline $\begin{array}{l}\text { Meyer et } \\
\text { al. (2015) } \\
{[44]}\end{array}$ & $\begin{array}{l}19, \\
\text { female }\end{array}$ & $\begin{array}{l}\text { Postural palpitations } \\
\text { ( } \mathrm{HR}=121-131 \mathrm{bpm} \text { on } \\
\text { standing) and } \\
\text { lightheadedness }\end{array}$ & - & 3 months & $\begin{array}{l}\text { Ivabradine alleviated } \\
\text { resting tachycardia, } \\
\text { postural palpitations, } \\
\text { and lightheadedness }\end{array}$ & - & $\begin{array}{l}\text { POTS followed a stressful event; patient } \\
\text { was a known case of DM type } 1 ; \\
\text { psychosocial support was given }\end{array}$ \\
\hline
\end{tabular}

\section{TABLE 4: Summary of case reports assessing effects of ivabradine in POTS}

HR: heart rate, bpm: beats per minute, BP: blood pressure, TD: three times a day, FIS: Fatigue Impact Scale, OGS: Orthostatic Grading Scale, CHB: complete heart block, PAF: paroxysmal atrial fibrillation, AV: atrioventricular, CSM: carotid sinus massage, AF: atrial fibrillation, LOC: loss of consciousness, DM: diabetes mellitus, POTS: postural orthostatic tachycardia syndrome

Before the administration of ivabradine, some patients had gone through other pharmacological treatment modalities for the relief of symptoms. In majority of the cases, the patients had a history of using betablockers while a few also reported alpha-blockers and CCBs [36-41]. In some cases, beta-blockers were discontinued due to poor tolerance whereas Oztunc et al. reported changing the treatment option to ivabradine due to no effective outcome from metoprolol and midodrine [36-38,40]. Another patient complied with the advice of maintaining hydration and taking fludrocortisone for several months only for her symptoms to persist [42].

The dosage of ivabradine in the mentioned nine cases varied from 2.5 to $5 \mathrm{mg}$ 12-hourly, and based on individual assessment of the patients, the dose was either tittered, maintained, or terminated (Table 4). The duration of treatment with ivabradine was variable with the earliest response observed just after two days of administration in a 25-year-old-female who had presented with symptoms for the past two weeks [43]. The patient did not experience symptoms of weakness or tachycardia on standing along with improvement in standing HR from 139 to $80 \mathrm{bpm}$. In other case reports, a complete resolution of syncopal episodes was also observed during the course of follow-up while the patient remained asymptomatic [39,41]. Almost all the other cases reported improvement in standing and supine HRs with a notable recovery from palpitations, tachycardia, and syncope $[36,37,42,44]$.

Although majority of the cases pointed towards the successful and effective outcomes of ivabradine in patients presenting with symptoms of POTS, two cases also brought forward the side effects experienced by patients during the treatment course. Nakatani et al. discussed the management by using ivabradine alongside AV node ablation and pacemaker implantation [40]. Although the drug effectively decreased the orthostatic symptoms, and resting and standing HRs, it, however, had to be discontinued due to some nonspecified adverse allergic reaction [40]. Another case was that of a 45 -years-old with POTS and dualchamber pacemaker [38]. A trial with an initial dose of $5 \mathrm{mg}$ in two doses was started and an improvement in supine and erect HRs was observed (from 107-140 to $80-90 \mathrm{bpm}$ ); however, mild symptoms of visual disturbances were reported. In light of the improved outcome in her HR and sinus tachycardia, the patient decided to continue with the therapy [38].

In 2018, Gee et al. conducted a meta-analysis and reviewed the available literature to evaluate the efficacy and safety of ivabradine for POTS treatment [45]. The authors included open-label trials and cohort studies with the outcomes of ivabradine in symptomatic POTS. This meta-analysis also evaluated case reports where patients with POTS symptoms were given ivabradine either as a first-line or a second-line drug following failure of beta-blockers to diminish the symptoms. At last, Gee et al. concluded that patients with symptomatic tachycardia, who have experienced failure of treatment with other pharmacologic therapies, can be benefited with a trial of ivabradine. The authors suggested further research to fully illustrate the role of ivabradine for treating POTS patients and to highlight the category of patients more prone to improve their symptoms [45].

\section{Conclusions}

In the light of the previously published literature (retrospective studies, case series, or case reports), we conclude that ivabradine can be safely used in patients with POTS symptoms as very few side effects have been reported along with a dramatic improvement in the symptoms like palpitations, syncope, and falls due 
to loss of consciousness. Ivabradine can be opted as a second-line treatment in patients with POTS as betablockers are mainly used at first. This review highlights that sometimes beta-blockers may fail to resolve the symptoms of POTS. In these scenarios, ivabradine can prove its effectiveness in abolishing the symptoms with uncommon or less severe side effects. To conclude, we recommend further research on the effectiveness of ivabradine that directly and selectively inhibits $\mathrm{I}_{\mathrm{f}}$ current in the SA node resulting in HR reduction in patients experiencing symptoms of POTS. Other than stable chronic angina pectoris, its application in this setting has been proven to be effective and safe. Further evaluation by means of randomized controls trials is required to encourage the use of this HR-lowering agent in common disorders other than HF and stable angina, i.e. POTS.

\section{Additional Information \\ Disclosures}

Conflicts of interest: In compliance with the ICMJE uniform disclosure form, all authors declare the following: Payment/services info: All authors have declared that no financial support was received from any organization for the submitted work. Financial relationships: All authors have declared that they have no financial relationships at present or within the previous three years with any organizations that might have an interest in the submitted work. Other relationships: All authors have declared that there are no other relationships or activities that could appear to have influenced the submitted work.

\section{References}

1. Da Costa JM: On irritable heart: a clinical study of a form of functional cardiac disorder and its consequences. Am J Med Sci. 1951, 11:559-567. 10.1016/0002-9343(51)90038-1

2. Schondorf R, Low PA: Idiopathic postural orthostatic tachycardia syndrome: an attenuated form of acute pandysautonomia?. Neurology. 1993, 43:132-137. 10.1212/wnl.43.1_part_1.132

3. Sheldon RS, Grubb BP, Olshansky B, et al.: 2015 Heart Rhythm Society expert consensus statement on the diagnosis and treatment of postural tachycardia syndrome, inappropriate sinus tachycardia, and vasovagal syncope. Heart Rhythm. 2015, 12:e41-e63. 10.1016/j.hrthm.2015.03.029

4. Zadourian A, Doherty TA, Swiatkiewicz I, Taub PR: Postural orthostatic tachycardia syndrome: prevalence, pathophysiology, and management. Drugs. 2018, 78:983-994. 10.1007/s40265-018-0931-5

5. Fedorowski A: Postural orthostatic tachycardia syndrome: clinical presentation, aetiology and management . J Intern Med. 2019, 285:352-366. 10.1111/joim.12852

6. Garland EM, Raj SR, Black BK, Harris PA, Robertson D: The hemodynamic and neurohumoral phenotype of postural tachycardia syndrome. Neurology. 2007, 69:790-798. 10.1212/01.wnl.0000267663.05398.40

7. Boris JR, Bernadzikowski T: Demographics of a large paediatric postural orthostatic tachycardia syndrome program. Cardiol Young. 2018, 28:668-674. 10.1017/S1047951117002888

8. AbdelRazek M, Low P, Rocca W, Singer W: Epidemiology of postural tachycardia syndrome . Neurology. 2019, 92:S18.005. Accessed: April 4, 2020: https://n.neurology.org/content/92/15_Supplement/S18.005.

9. Garland EM, Celedonio JE, Raj SR: Postural tachycardia syndrome: beyond orthostatic intolerance . Curr Neurol Neurosci Rep. 2015, 15:60. Accessed: April 4, 2020: 10.1007/s11910-015-0583-8

10. Raj SR: Postural tachycardia syndrome (POTS). Circulation. 2013, 127:2336-2342. 10.1161/CIRCULATIONAHA.112.144501

11. Johnson JN, Mack KJ, Kuntz NL, Brands CK, Porter CJ, Fischer PR: Postural orthostatic tachycardia syndrome: a clinical review. Pediatr Neurol. 2010, 42:77-85. 10.1016/j.pediatrneurol.2009.07.002

12. Sutton R, Salukhe TV, Franzen-Mcmanus AC, Collins A, Lim PB, Francis DP: Ivabradine in treatment of sinus tachycardia mediated vasovagal syncope. Europace. 2014, 16:284-288. 10.1093/europace/eut226

13. Barzilai M, Jacob G: The effect of ivabradine on the heart rate and sympathovagal balance in postural tachycardia syndrome patients. Rambam Maimonides Med J. 2015, 6:e0028. Accessed: April 4, 2020: 10.5041/RMMJ.10213

14. McDonald C, Frith J, Newton JL: Single centre experience of ivabradine in postural orthostatic tachycardia syndrome. Europace. 2011, 13:427-430. 10.1093/europace/euq390

15. Delle Donne G, Noguer FR, Till J, Salukhe T, Prasad SK, Daubeney PEF: Ivabradine in postural orthostatic tachycardia syndrome: preliminary experience in children. Am J Cardiovasc Drugs. 2018, 18:59-63. 10.1007/s40256-017-0248-x

16. Ruzieh M, Sirianni N, Ammari Z, Dasa O, Alhazmi L, Karabin B, Grubb B: Ivabradine in the treatment of postural tachycardia syndrome (POTS), a single center experience. Pacing Clin Electrophysiol. 2017, 40:1242-1245. 10.1111/pace.13182

17. Reed M, Nicolas D: Ivabradine. StatPearls [Internet], Treasure Island; 2019.

18. Koruth JS, Lala A, Pinney S, Reddy VY, Dukkipati SR: The clinical use of ivabradine . J Am Coll Cardiol. 2017, 70:1777-1784. 10.1016/j.jacc.2017.08.038

19. Task Force Members, Montalescot G, Sechtem U, et al.: 2013 ESC guidelines on the management of stable coronary artery disease: the Task Force on the management of stable coronary artery disease of the European Society of Cardiology. Eur Heart J. 2013, 34:2949-3003. 10.1093/eurheartj/eht296

20. Corlanor (ivabradine tablets) prescribing information. (2015). Accessed: April 4, 2020 : https://www.pi.amgen.com/ /media/amgen/repositorysites/pi-amgen-com/corlanor/corlanor pi.pdf.

21. Simon L, Ghaleh B, Puybasset L, Giudicelli JF, Berdeaux A: Coronary and hemodynamic effects of S 16257, a new bradycardic agent, in resting and exercising conscious dogs. J Pharmacol Exp Ther. 1995, 275:659-666.

22. Robertson D: The epidemic of orthostatic tachycardia and orthostatic intolerance . Am J Med Sci. 1999, 317:75-77. 10.1097/00000441-199902000-00001

23. Benarroch EE: Postural tachycardia syndrome: a heterogeneous and multifactorial disorder . Mayo Clin Proc. 2012, 87:1214-1225. 10.1016/j.mayocp.2012.08.013 
24. Jacob G, Costa F, Shannon JR, et al.: The neuropathic postural tachycardia syndrome. N Engl J Med. 2000, 343:1008-1014. 10.1056/NEJM200010053431404

25. Shannon JR, Flattem NL, Jordan J, et al.: Orthostatic intolerance and tachycardia associated with norepinephrine-transporter deficiency. N Engl J Med. 2000, 342:541-549. 10.1056/NEJM200002243420803

26. Streeten DH, Thomas D, Bell DS: The roles of orthostatic hypotension, orthostatic tachycardia, and subnormal erythrocyte volume in the pathogenesis of the chronic fatigue syndrome. Am J Med Sci. 2000, 320:1-8. 10.1097/00000441-200007000-00001

27. Raj SR, Biaggioni I, Yamhure PC, Black BK, Paranjape SY, Byrne DW, Robertson D: Renin-aldosterone paradox and perturbed blood volume regulation underlying postural tachycardia syndrome. Circulation. 2005, 111:1574-1582. 10.1161/01.CIR.0000160356.97313.5D

28. Bryarly M, Phillips LT, Fu Q, Vernino S, Levine BD: Postural orthostatic tachycardia syndrome: JACC focus seminar. J Am Coll Cardiol. 2019, 73:1207-1228. 10.1016/j.jacc.2018.11.059

29. Blitshteyn S: Autoimmune markers and autoimmune disorders in patients with postural tachycardia syndrome (POTS). Lupus. 2015, 24:1364-1369. 10.1177/0961203315587566

30. Fu Q, Vangundy TB, Galbreath MM, et al.: Cardiac origins of the postural orthostatic tachycardia syndrome . J Am Coll Cardiol. 2010, 22:2858-2868. 10.1016/j.jacc.2010.02.043

31. Fu Q, Levine BD: Exercise and non-pharmacological treatment of POTS . Auton Neurosci. 2018, 215:20-27. 10.1016/j.autneu.2018.07.001

32. Riccioni G: Ivabradine: recent and potential applications in clinical practice . Expert Opin Pharmacother. 2011, 12:443-450. 10.1517/14656566.2011.548321

33. Sathyamurthy I, Newale S: Ivabradine: evidence and current role in cardiovascular diseases and other emerging indications. Indian Heart J. 2018, 70:S435-S441. 10.1016/j.ihj.2018.08.008

34. Elzir L, O’Meara E, Denus SD, Tardif JC: Ivabradine for the treatment of heart failure . Clin Investig. 2014, 4:555-565.

35. Oliphant CS, Owens RE, Bolorunduro OB, Jha SK: Ivabradine: a review of labeled and off-label uses . Am J of Cardiovasc Drugs. 2016, 16:337-347. 10.1007/s40256-016-0178-z

36. Oztunc F, Atik SU, Dedeoglu R, Alp FE, Gokalp S: Cooccurrence of postural orthostatic tachycardia syndrome with two different clinical entities. Case Rep Pediatr. 2016, 2016:e8542158. Accessed: April 4, 2020: 10.1155/2016/8542158

37. Ewan V, Norton M, Newton JL: Symptom improvement in postural orthostatic tachycardia syndrome with the sinus node blockerivabradine. Europace. 2007, 9:1202. 10.1093/europace/eum235

38. Khan S, Hamid S, Rinaldi C: Treatment of inappropriate sinus tachycardia with ivabradine in a patient with postural orthostatic tachycardia syndrome and a dual chamber pacemaker. Pac Clin Electrophysiol. 2009, 32:131-133. 10.1111/j.1540-8159.2009.02186.x

39. Jamil-Copley S, Nagarajan DV, Baig MK: Use of ivabradine in postural orthostatic tachycardia syndrome . J Atr Fibrillation. 2010, 3:273.

40. Nakatani Y, Mizumaki K, Nishida K, Inoue H: Atrioventricular node ablation and pacemaker implantation for recurrent syncope in a patient with postural tachycardia syndrome (POTS). J Cardiovasc Electrophysiol. 2011, 22:1284-1287. 10.1111/j.1540-8167.2011.02078.x

41. Aliyev FC, Eliker C, Türkoğlu C, Uzunhasan I: Successful use of ivabradine in a case of exaggerated autonomic dysfunction. Turk Kardiyol Dern Ars. 2010, 38:285-289.

42. Cheema MA, Zain MA, Ullah W, Cheema K: Is ivabradine a wonder drug for atypical POTS? . BMJ Case Rep. 2019, 12:e227789. Accessed: April 5, 2020: 10.1136/bcr-2018-227789

43. Hersi AS: Potentially new indication of ivabradine: treatment of a patient with postural orthostatic tachycardia syndrome. Open Cardiovasc Med J. 2010, 4:166-167. 10.2174/1874192401004010166

44. Meyer C, Mühlsteff J, Drexel T, Eickholt C, Kelm M, Zahiragic L, Ziegler L: POTS following traumatic stress: interacting central and intracardiac neural control?. J Diabetes Complicat. 2015, 29:459-461. 10.1016/j.jdiacomp.2015.02.003

45. Gee ME, Watkins AK, Brown JN, Young EJA: Ivabradine for the treatment of postural orthostatic tachycardia syndrome: a systematic review. Am J Cardiovasc Drugs. 2018, 18:195-204. 10.1007/s40256-017-0252-1 